\title{
Synthesis and Anxiolytic Activity of 2- (Substituted)-5-[(N-Benzotriazolomethyl)-1,3, 4-Thiadiazolyl]-4-Thiazolidinone
}

\author{
V K Singh*1, Peeyush Bharadwaj ${ }^{1}$ and Poonam Rishishwar ${ }^{2}$ \\ ${ }^{1}$ Bundelkhand University, India \\ ${ }^{2}$ School of Pharmaceutical Sciences, Sri Venkateshwara University, India
}

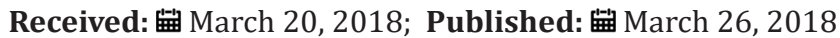

*Corresponding author: VK Singh, Bundelkhand University, India

\begin{abstract}
1,2,3-Benzotriazole (BTA) is a heterocyclic compound with three nitrogen atoms. It is a polar and colourless compound which can be used for its great versatility. The enormous investigations on derivatives of benzotriazole reveal wide applicability of this molecule for tagging and delivering huge number of heterocyclic nuclei. In the present work synthesis of several derivatives of 2-(substituted)-5-[(n-benzotriazolomethyl)-1,3,4-thiadiazolyl]-4-thiazolidinone has been synthesized and are evaluated for their anxiolytic activity. The antianxiety activities of the synthesized derivatives were evaluated using EPM test and Bright and dark box test experimental models of anxiety. All results were expressed as mean \pm standard error mean (SEM) and analysed by one-way ANOVA. Post-hoc comparisons were performed by applying Dunnet's test. $\mathrm{P}<0.05$ was considered statistically significant
\end{abstract}

Keywords: Benzotriazole; Thiadiazole; Thiazolidinone; Anxiolytic Activity; Anxiety; Elevated Plus Maize; Bright and Dark Arena

Abbreviations: IP: Intraperitoneally; IAEC: Institutional Animal Ethics Committee; SEM: Standard Error Mean

\section{Introduction}

1,2,3-benzotriazoles were reported to have potential fungicidal [1] and antibacterial activity [2]. Similarly 1,3,4-thiadiazole derivatives were also reported to possess fungicidal, herbicidal, bactericidal [3], pesticidal, insecticidal, antihistaminic, antiamoebic [4], CNS depressant, antihypertensive, anticonvulsant, hypnotic, analgesic [5], anti-inflammatory [6] and agonist for 5-Ht receptor [7]. 4-thiazolidinone nucleus has also occupied a unique place in the field of medicinal chemistry due to its wide range of biological activities like antibacterial, anticancer [8], Respiratory, syncytial, virus Inhibitor [9], anticonvulsant [10], sciatic nerve blocking, local anaesthetic, inhibitors of human (CK2) protein kinase [11], hypnotic, fungicidal, cysticidal, anti leukemic and antioxidant activity. In view of potential biological activities of benzotriazole, thiadiazole and 4-thiazolidinone an attempt has made to unite these nuclei together and synthesize some new derivatives of benzotriazole $\left(\mathrm{X}_{1}-\mathrm{X}_{6}\right)$ to probe how far these combinations could develop anxiolytic activity. The procedure of synthesis has been outlined in Figure 1.
Anxiety is a normal emotional response which when chronic or severe becomes pathological and can aggravate cardiovascular and psychiatric disorders [12]. Despite the development of new molecules for pharmacotherapy of anxiety, the treatment is challenging as they produce various side effects or exhibit tolerance on continuous use.

\section{Materials and Methods}

The chemicals and reagents used in this were of AR and LR grade. They were procured from $\mathrm{CDH}$, Hi-Media, Merck, Sigma Aldrich and Ranbaxy. The melting points of the synthesized compounds were determined by using Thiel's melting point apparatus (open capillary tube method) and all the compounds gave sharp melting points and are uncorrected. Purity of the compounds was ascertained by thin layer chromatography using silica gel-G as stationary phase and appropriate mixtures of the following solvents as mobile phase: n-butanol, glacial acetic acid and water. The spots resolved were visualized using iodine chamber. The IR 
spectra of the synthesized compounds were recorded on a Fourier Transform IR spectrophotometer (Perkin Elimer BX-II) in the range of 400-4000 using diffuse reflectance system and values of vmax are reported in $\mathrm{cm}^{-1}$. $1 \mathrm{H}$ NMR spectra were recorded on Bruker AvII $400 \mathrm{MHz}$ NMR spectrometer and chemical shifts $(\delta)$ are reported in ppm downfield from internal reference Tetramethylsilane (TMS). Mass spectra were recorded on Shimadzu LC-MS model 2010A. Elemental analysis of the newly synthesized compounds was carried out using Euro - E 3000 series elemental analyzer. 2-(substituted)-5-[(n-benzotriazolomethyl)-1,3,4-thiadiazolyl]-4thiazolidinone were prepared as per the method described in the literature [13-15]. The Synthetic Procedure involved the following six steps as stated below.

i. Step 1: Synthesis of Benzotriazole: In a mixture of 11.5 $\mathrm{ml}$ glacial acetic acid and $30 \mathrm{ml}$ water, $0.1 \mathrm{M} \mathrm{o}$-phenylenediamine was dissolved and then added a solution of $0.1 \mathrm{M} \mathrm{NaNO}_{2}$ in $15 \mathrm{ml}$ of water, stirred continuously for 15 minutes. The temperature was maintained at $120 \mathrm{C}$, chilled in ice bath and product (i) was collected by filtration. The yield obtained was $85 \%$ and M.P. was 990C.

ii. Step 2: Synthesis of N-Benzotriazolacetate: A mixture of product (i) $0.1 \mathrm{M}$, ethylacetate $(0.1 \mathrm{M})$ and 0.3 gm of $\mathrm{K}_{2} \mathrm{CO}_{3}$ in $60 \mathrm{ml}$ of acetone was stirred of $10 \mathrm{hrs}$. The solvent was removed under reduced pressure. A solid $m$ ass was produced which gave needle shaped crystals after recrystallization from the mixture of chloroform and ether $(8: 2 \% \mathrm{~V} / \mathrm{V})$. The yield obtained was $70 \%$ and M.P. was $400 \mathrm{C}$.

iii. Step 3: Synthesis of N-Benzotriazol Acetyl Thiosemicarbazide: The crystals obtained from step II

$(0.08 \mathrm{M})$ and thiosemicarbazide $(0.08 \mathrm{M})$ were taken in $50 \mathrm{ml}$ of ethanol, stirred for $6 \mathrm{hrs}$ and then refluxed for $3 \mathrm{hrs}$. The yellow coloured compound was obtained after recrystallization from the mixture of chloroform and hexane $(9: 1 \% \mathrm{~V} / \mathrm{V})$. The yield was $60 \%$ and M.P. 1030 C.

iv. Step 4: Synthesis of 2-Amino-5-(NBenzotriazolomethyl)-1,3,4-Thiadiazole: Compound ii $(0.08 \mathrm{M})$ was added in conc. $\mathrm{H}_{2} \mathrm{SO}_{4}$ and kept overnight at room temperature, then neutralized with ammonia and extracted with ether. The ether was distilled off and the product recrystallized from methanol, the yield was 52\% and M.P. $1210 \mathrm{C}$.

v. Step 5: Synthesis of 2-Benzylidenylamino-5-(NBenzotriazolomethyl)-1,3,4-Thiadiazole: Compound iv $(0.02 \mathrm{M})$, carbonyl compound $\left(\mathrm{R}_{1} \mathrm{R}_{2} \mathrm{C}=0\right)$ (Table 1 ) and glacial acetic acid (2ml) were refluxed in $50 \mathrm{ml}$ methanol for $8 \mathrm{hrs}$. Solvent was distilled off and product recrystallised from the mixture of benzene and chloroform (1:6 \%V/V). M.P. was 1290C and the yield was 50\%.

Table 1: $R_{1}$ and $R_{2}$ values for compound $X_{1}$ to $X_{6}$.

\begin{tabular}{|c|c|c|}
\hline Compounds & $\mathbf{R}_{\mathbf{1}}$ & $\mathbf{R}_{\mathbf{2}}$ \\
\hline $\mathrm{X}_{1}$ & $\mathrm{H}$ & $-\mathrm{C}_{6} \mathrm{H}_{5}$ \\
\hline $\mathrm{X}_{2}$ & $-\mathrm{C}_{6} \mathrm{H}_{5}$ & $-4 \mathrm{Br}-\mathrm{C}_{6} \mathrm{H}_{5}$ \\
\hline $\mathrm{X}_{3}$ & $\mathrm{H}$ & $-4 \mathrm{Cl}-\mathrm{C}_{6} \mathrm{H}_{5}$ \\
\hline $\mathrm{X}_{4}$ & $\mathrm{CH}_{3}$ & $\mathrm{C}_{6} \mathrm{H}_{5}$ \\
\hline $\mathrm{X}_{5}$ & $\mathrm{CH}_{3}$ & $\mathrm{C}_{2} \mathrm{H}_{5}$ \\
\hline $\mathrm{X}_{6}$ & $\mathrm{C}_{6} \mathrm{H}_{5}$ & $\mathrm{C}_{6} \mathrm{H}_{5}$ \\
\hline
\end{tabular}

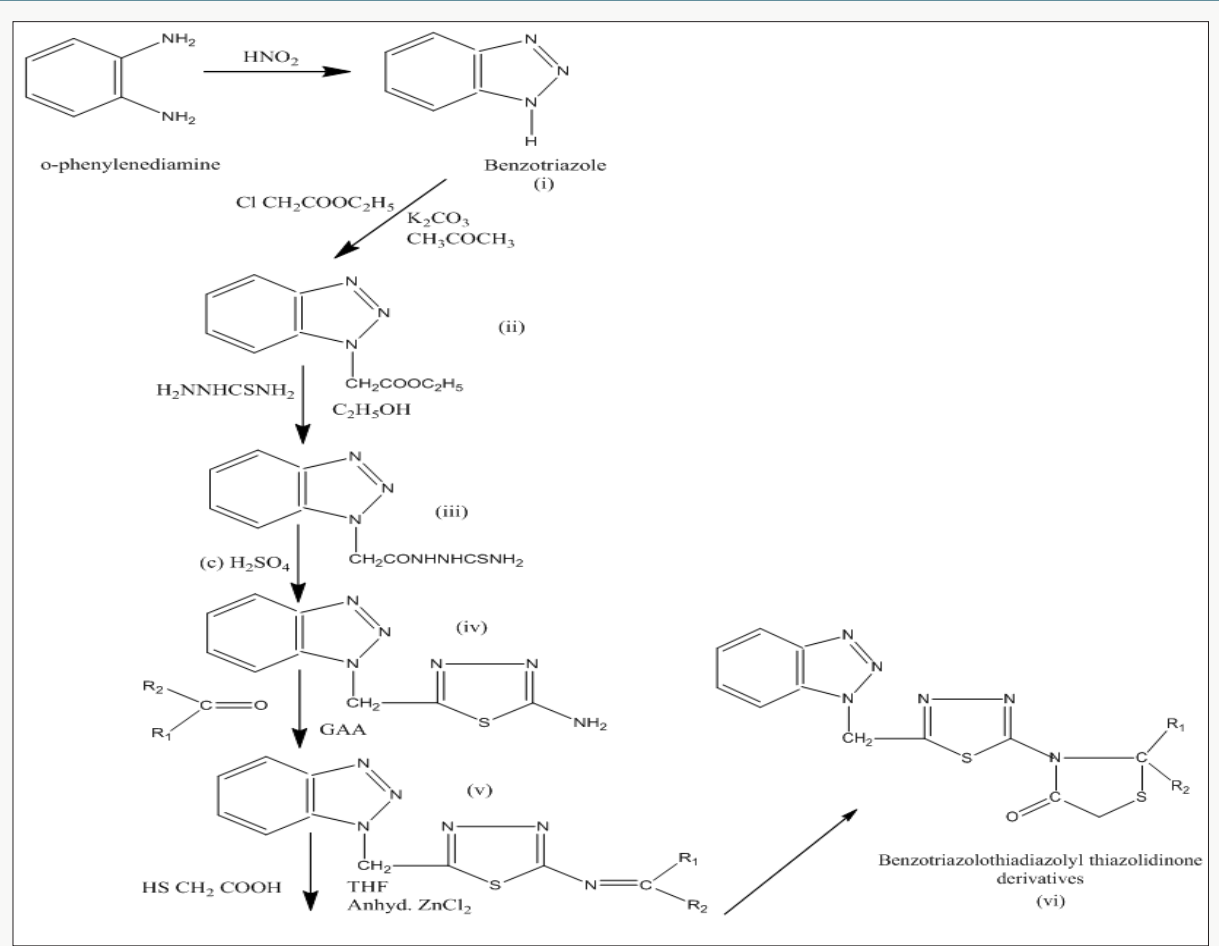

Figure 1.

Citation: V K Singh, Peeyush B, Poonam R. Synthesis and Anxiolytic Activity of 2-(Substituted)-5-[(N-Benzotriazolomethyl)-1,3, 4-Thiadiazolyl]-4-Thiazolidinone. Drug Des Int Prop Int J 1(1)- 2018. DDIPIJ.MS.ID.000104. DOI: 10.32474/DDIPIJ.2018.01.000104. 
vi. Step 6: Synthesis of 2-(Phenyl)-5-[(N-Benzotriazolomethyl)-1,3,4-Thiadiazolyl]-4-Thiazolidinone: The compound (v) $0.01 \mathrm{M}$ and mercapto acetic acid $(10 \mathrm{ml})$ with a pinch of anhydrous $\mathrm{ZnCl}_{2}$ were added in $30 \mathrm{ml}$ of tetrahydrofuran and refluxed for $12 \mathrm{hrs}$ on water bath. The product was separated and recrystallised from ethanol. The M.P. was 1380C and yield was 58\%. The purity of synthesised compounds were established by TLC using $2 \%$ silica gel G, n-butanol: glacial acetic acid: water (4:1:5). The M.P. of synthesized compounds $\mathrm{X}_{1}$ to $\mathrm{X}_{6}$ was found to be $1380 \mathrm{C}, 1300 \mathrm{C}, 1630 \mathrm{C}, 1560 \mathrm{C}, 1220 \mathrm{C}$ and $1260 \mathrm{C}$ respectively (Figure 1 ).

Structures of the compounds were established on the basis of C, $\mathrm{H}$ and $\mathrm{N}$ analysis reports, IR and $1 \mathrm{H}-\mathrm{NMR}$ spectra (Table 2).

Table 2: Spectral data of 2-(substituted)-5-[(n-benzotriazolomethyl)-1,3,4-thiadiazolyl]-4-thiazolidinone.

\begin{tabular}{|c|c|c|}
\hline Type & Associated Vibration & Frequency $\left(\mathbf{i n ~} \mathbf{~ c m}^{-1}\right.$ ) \\
\hline Thiazolidinone ring & >C=O str. & 1739 \\
\hline & C-S str. & 752 \\
\hline & C-N str. & 1333 \\
\hline & C=N str. & 1670 \\
\hline Thiadiazole ring & N-N str. & 1626.7 \\
\hline & C=N str. & 1670 \\
\hline Benzotriazole ring & C-S str. & 641 \\
\hline & C-N str. & 1271.39 \\
\hline & C=C str. & 1536.15 \\
\hline & Ar-H str. & 3044.19 \\
\hline & N=N str. & 1382 \\
\hline
\end{tabular}

(a) Interpretation of IR spectra:

\begin{tabular}{|c|c|c|}
\hline Signal position & Relative No. of protons & Inference \\
\hline $7.68-7.36$ & $9 \mathrm{H}$ & $\mathrm{Ar}-\mathrm{H}$ \\
\hline 4.65 & $2 \mathrm{H}$ & $-\mathrm{CH}_{2}$ of thiazolidinone \\
\hline 8.00 & $1 \mathrm{H}$ & $-\mathrm{CH}$ of thiazolidinone \\
\hline $3.97-3.85$ & $2 \mathrm{H}$ & $-\mathrm{S}-\mathrm{CH}_{2}-\mathrm{C}$ thiazolidinone \\
\hline
\end{tabular}

(b) Interpretation of $1 \mathrm{H}-\mathrm{NMR}$ spectra:

\section{Determination of Anxiolytic Activity}

\section{Methods}

Preparation of DMF (Dimethylformamide) Suspension of Synthesized Compounds: All synthesized compounds were dissolved in DMF and used as a suspension in physiological saline containing 2 drops of Tween 80 and produce a final conc. of 0.2 $\mathrm{mg} / \mathrm{ml}$. The standard drug used for this study was diazepam. Drugs were administered intraperitoneally (IP) in a constant volume of 1 $\mathrm{ml} / \mathrm{kg}$, $60 \mathrm{~min}$ before experiments were carried out.

Animals: Adult male Swiss albino mice weighing 25-35g obtained from our animal house. The animals were housed at 24 $\pm 20 \mathrm{C}$ with 12: $12 \mathrm{~h}$ light and dark cycle. They had free access to food and water. The animals were acclimatized for a period of 7 days before the study. The experimental protocol was approved by the Institutional Animal Ethics Committee (IAEC) of Institute of Pharmacy, Bundelhand University, Jhansi (U.P.) India. The animals were used according to the CPCSEA guidelines for the use and care of experimental animals.

Experimental Design: On the day of the experiment, the animals were divided randomly into control and experimental groups $(n=6)$. Group 1 received the vehicle, normal saline $(10 \mathrm{ml} / \mathrm{kg})$ and served as the control group, group 2 received the standard drug diazepam $(2 \mathrm{mg} / \mathrm{kg})$ and group 3 to 8 received DMF suspension of synthesized compounds $\left(\mathrm{X}_{1}\right.$ to $\mathrm{X}_{6}$ ) (Table 3 ). Drugs were administered to the animals 60 minutes prior to the evaluation in acute study, for chronic study once daily for a period of 10 days. Behavioural evaluation was carried out 60 minutes post drug administration on the 10th day. The antianxiety activity of the test drug was evaluated using EPM (elevated plus maze) test and Bright and dark box test experimental models of anxiety.

Table 3: Experimental design.

\begin{tabular}{|c|c|c|}
\hline Groups & Treatment & Dose \\
\hline I & Normal Saline & $10 \mathrm{ml} / \mathrm{kg}$ \\
\hline II & Diazepam & $2 \mathrm{mg} / \mathrm{Kg}$ \\
\hline III & Compound $\mathrm{X}_{1}$ & $2 \mathrm{mg} / \mathrm{Kg}$ \\
\hline IV & Compound $\mathrm{X}_{2}$ & $2 \mathrm{mg} / \mathrm{Kg}$ \\
\hline V & Compound $\mathrm{X}_{3}$ & $2 \mathrm{mg} / \mathrm{Kg}$ \\
\hline VI & Compound $\mathrm{X}_{4}$ & $2 \mathrm{mg} / \mathrm{Kg}$ \\
\hline VII & Compound $\mathrm{X}_{5}$ & $2 \mathrm{mg} / \mathrm{Kg}$ \\
\hline VIII & Compound $\mathrm{X}_{6}$ & $2 \mathrm{mg} / \mathrm{Kg}$ \\
\hline
\end{tabular}

\section{Evaluation of Antianxiety Activity}

\section{Elevated Plus Maze Test}

According to the method of Kulkarni SK et al. [16] The wooden maze consisted of two open arms $(50 \mathrm{~cm} \times 10 \mathrm{~cm})$ and two closed arms of $(50 \mathrm{~cm} \times 10 \mathrm{~cm} \times 40 \mathrm{~cm})$. The arms of same type were opposite to each other with a central square of $10 \mathrm{~cm}$. The maze was elevated to a height of $50 \mathrm{~cm}$ above the floor. Each animal was placed in the centre square of plus maze, facing one of the open arms. The number of entries into and the time spent in open and closed arms in a 5 min period was noted.

\section{Bright and Dark}

The apparatus consisted of an open top wooden box. Two distinct chambers, a black chamber $(20 \times 30 \times 35 \mathrm{~cm})$ painted black and illuminated with dimmed red light and a bright chamber $(30 \times 30 \times 35 \mathrm{~cm})$ painted white and brightly illuminated with 100 W white light sources, were located $17 \mathrm{~cm}$ above the box. The two chambers were connected through a small open doorway $(7.5 \times 5 \mathrm{~cm})$ situated on the floor level at the centre of the partition [17]. 


\section{Behavioural Assessment}

Each animal was tested initially in plus maze and, then, in bright and dark arena paradigm in a single setting. In acute study $60 \mathrm{~min}$ after and in chronic study $60 \mathrm{~min}$ after the last dose on the $10^{+}$day of drug or vehicle administration, each animal was placed in the centre square of the plus maze, facing one of the open arms. The number of entries into and the time spent in open and closed arms and the number of rears in each arm in a five-minute period was noted. Following the elevated plus maze test, the animal was placed at the centre of the brightly lit arena in the light and dark box. The number of entries into and the time spent in the bright arena, the number of rears in the bright arenas were noted. Following each trial, the apparatus were cleaned to mask the odour left by the animal in the previous experiment. Hand operated counters and stop watches were used to score the behaviour of animals.

\section{Statistical Analysis}

All results were expressed as mean \pm standard error mean (SEM) and analysed by one-way ANOVA. Post-hoc comparisons were performed by applying Dunnet's test. $\mathrm{P}<0.05$ was considered statistically significant.

Table 4: Acute effect of synthesized compounds on behaviour of mice in elevated plus maze.

\begin{tabular}{|c|c|c|c|c|}
\hline Groups & $\begin{array}{c}\text { Number of open arm } \\
\text { entries }\end{array}$ & $\begin{array}{c}\text { Number of total arm } \\
\text { entries }\end{array}$ & Time spent in open arm (Sec.) & $\begin{array}{c}\text { Time spent in closed arm } \\
\text { (Sec.) }\end{array}$ \\
\hline Control & $3.16 \pm 0.47$ & $6.50 \pm 0.72$ & $27.00 \pm 0.97$ & $182.67 \pm 2.33$ \\
\hline Diazepam $(2 \mathrm{mg} / \mathrm{kg})$ & $8.50 \pm 0.67^{*}$ & $11.50 \pm 1.48^{*}$ & $100.66 \pm 1.33^{*}$ & $139.50 \pm 3.31^{*}$ \\
\hline $\mathrm{X}_{1}(2 \mathrm{mg} / \mathrm{kg})$ & $5.12 \pm 0.54^{*}$ & $7.64 \pm 1.44^{*}$ & $84.45 \pm 1.22^{*}$ & $122.34 \pm 3.30^{*}$ \\
\hline $\mathrm{X}_{2}(2 \mathrm{mg} / \mathrm{kg})$ & $7.33 \pm 0.49^{*}$ & $10.66 \pm 1.69^{*}$ & $88.50 \pm 1.34^{*}$ & $152.50 \pm 2.17^{*}$ \\
\hline $\mathrm{X}_{3}(2 \mathrm{mg} / \mathrm{kg})$ & $6.33 \pm 0.66^{*}$ & $9.16 \pm 0.70^{*}$ & $86.83 \pm 0.79^{*}$ & $164.67 \pm 2.20^{*}$ \\
\hline $\mathrm{X}_{4}(2 \mathrm{mg} / \mathrm{kg})$ & $5.87 \pm 0.62^{*}$ & $8.56 \pm 0.85^{*}$ & $85.34 \pm 0.83^{*}$ & $134.44 \pm 2.10^{*}$ \\
\hline $\mathrm{X}_{5}(2 \mathrm{mg} / \mathrm{kg})$ & $4.56 \pm 0.56^{*}$ & $7.12 \pm 0.45^{*}$ & $75.07 \pm 0.67^{*}$ & $120.22 \pm 1.06^{*}$ \\
\hline $\mathrm{X}_{6}(2 \mathrm{mg} / \mathrm{kg})$ & $5.83 \pm 0.62^{*}$ & $8.84 \pm 0.85^{*}$ & $84.34 \pm 0.94^{*}$ & $138.87 \pm 2.87^{*}$ \\
\hline
\end{tabular}

\section{Results}

\section{Elevated Plus-Maze}

A perusal of Table 4 shows that compared to the standard drug, the synthesized compounds $\mathrm{X}_{2}$ and $\mathrm{X}_{3}$ significantly increased open arm activity, increasing the duration of time spent and number of entries in open arm in EPM test compared to control in acute study but in chronic study the doses of $\mathrm{X}_{2}$ and $\mathrm{X}_{3}$ produced a greater increase in duration of time spent and number of entries in open arm in EPM test compared to both control and standard drug diazepam. $\mathrm{X}_{2}$ had produced better effect than $\mathrm{X}_{3}$ and Diazepam in chronic study (Tables 4 \& 5).

Table 5: Chronic effect of synthesized compounds on behaviour of mice in elevated plus maze.

\begin{tabular}{|c|c|c|c|c|}
\hline Groups & Number of open arm entries & Number of total arm entries & Time spent in open arm & Time spent in closed arm \\
\hline Control & $4.39 \pm 0.94$ & $8.35 \pm 0.65$ & $29.48 \pm 1.52$ & $234.92 \pm 2.79$ \\
\hline Diazepam (2mg/kg) & $8.05 \pm 0.62^{*}$ & $11.97 \pm 1.36^{*}$ & $88.93 \pm 1.07^{*}$ & $197.08 \pm 2.32^{*}$ \\
\hline $\mathrm{X}_{1}(2 \mathrm{mg} / \mathrm{kg})$ & $6.04 \pm 0.67 *$ & $10.34 \pm 1.24 *$ & $92.78 \pm 1.02^{*}$ & $134.45 \pm 2.32^{*}$ \\
\hline $\mathrm{X}_{2}(2 \mathrm{mg} / \mathrm{kg})$ & $10.22 \pm 0.78^{* *}$ & $15.30 \pm 0.70^{* *}$ & $104.09 \pm 1.24^{* *}$ & $158.02 \pm 2.12^{* *}$ \\
\hline $\mathrm{X}_{3}(2 \mathrm{mg} / \mathrm{kg})$ & $9.60 \pm 1.06^{*}$ & $15.00 \pm 1.33^{*}$ & $102.87 \pm 0.80^{*}$ & $170.32 \pm 1.39 *$ \\
\hline $\mathrm{X}_{4}(2 \mathrm{mg} / \mathrm{kg})$ & $7.88 \pm 1.08^{*}$ & $13.56 \pm 0.87^{*}$ & $96.56 \pm 1.34 *$ & $156.45 \pm 1.56^{*}$ \\
\hline $\mathrm{X}_{5}(2 \mathrm{mg} / \mathrm{kg})$ & $5.24 \pm 0.87^{*}$ & $9.23 \pm 0.56^{*}$ & $91.44 \pm 0.87^{*}$ & $140.56 \pm 1.34^{*}$ \\
\hline $\mathrm{X}_{6}(2 \mathrm{mg} / \mathrm{kg})$ & $7.86 \pm 1.08^{*}$ & $13.98 \pm 0.98 *$ & $103.67 \pm 0.76^{*}$ & $165.34 \pm 1.67^{*}$ \\
\hline
\end{tabular}

Values represented mean \pm SEM $(\mathrm{n}=6),{ }^{*} \mathrm{P}<0.05$ vs. control, ${ }^{* *} \mathrm{P}<0.05$ vs. standard.

\section{Bright and Dark}

Diazepam $(1 \mathrm{mg} / \mathrm{kg})$ treated mice significantly increased the number of entries into the bright arena, the time spent and the rears in bright arena. In acute study, both $\mathrm{X}_{2}$ and $\mathrm{X}_{3}$ significantly

Table 6: Acute effect of synthesized compounds on behaviour of mice in bright and dark arena.

\begin{tabular}{|c|c|c|c|}
\hline Groups & Number of bright chamber entries & Time spent bright chamber (sec) & Number of rears in bright chamber \\
\hline Control & $1.6 \pm 0.61$ & $5.16 \pm 0.30$ & $1.09 \pm 0.31$ \\
\hline Diazepam $(2 \mathrm{mg} / \mathrm{kg})$ & $2.66 \pm 0.23^{*}$ & $14.83 \pm 0.71^{*}$ & $3.32 \pm 0.75^{*}$ \\
\hline
\end{tabular}




\begin{tabular}{|l|l|l|l|}
\hline$X_{1}(2 \mathrm{mg} / \mathrm{kg})$ & $1.78 \pm 0.22^{*}$ & $12.45 \pm 0.65^{*}$ & $2.98 \pm 0.42^{*}$ \\
\hline$X_{2}(2 \mathrm{mg} / \mathrm{kg})$ & $2.74 \pm 0.21^{*}$ & $39.33 \pm 0.86^{*}$ & $3.18 \pm 0.74^{*}$ \\
\hline$X_{3}(2 \mathrm{mg} / \mathrm{kg})$ & $2.45 \pm 0.45^{*}$ & $26.16 \pm 0.64^{*}$ & $2.80 \pm 0.15^{*}$ \\
\hline$X_{4}(2 \mathrm{mg} / \mathrm{kg})$ & $2.12 \pm 0.02^{*}$ & $14.11 \pm 0.45^{*}$ & $2.55 \pm 0.34^{*}$ \\
\hline$X_{5}(2 \mathrm{mg} / \mathrm{kg})$ & $1.33 \pm 0.56^{*}$ & $11.45 \pm 0.48^{*}$ & $1.67 \pm 0.26^{*}$ \\
\hline$X_{6}(2 \mathrm{mg} / \mathrm{kg})$ & $2.65 \pm 0.67^{*}$ & $15.78 \pm 0.55^{*}$ & $2.45 \pm 0.35^{*}$ \\
\hline
\end{tabular}

Values represented mean \pm SEM $(n=6), * P<0.05$ vs. control.

Table 7: Chronic effect of synthesized compounds on behaviour of mice in bright and dark arena.

\begin{tabular}{|c|c|c|c|}
\hline Groups & Number of bright chamber entries & Time spent bright chamber (sec) & Number of rears in bright chamber \\
\hline Control & $1.31 \pm 0.73$ & $5.44 \pm 1.02$ & $2.18 \pm 0.24$ \\
\hline Diazepam $(2 \mathrm{mg} / \mathrm{kg})$ & $3.12 \pm 0.42^{*}$ & $16.23 \pm 0.12^{*}$ & $4.62 \pm 0.49^{*}$ \\
\hline $\mathrm{X}_{1}(2 \mathrm{mg} / \mathrm{kg})$ & $2.78 \pm 0.45^{*}$ & $38.87 \pm 0.22^{*}$ & $2.45 \pm 0.44^{*}$ \\
\hline $\mathrm{X}_{2}(2 \mathrm{mg} / \mathrm{kg})$ & $5.35 \pm 0.27^{* *}$ & $45.31 \pm 0.94^{* *}$ & $6.76 \pm 0.35^{* *}$ \\
\hline $\mathrm{X}_{3}(2 \mathrm{mg} / \mathrm{kg})$ & $3.76 \pm 0.23^{*}$ & $29.71 \pm 0.43^{*}$ & $4.94 \pm 0.28^{*}$ \\
\hline $\mathrm{X}_{4}(2 \mathrm{mg} / \mathrm{kg})$ & $2.99 \pm 0.34^{*}$ & $35.68 \pm 0.21^{*}$ & $3.32 \pm 0.34^{*}$ \\
\hline $\mathrm{X}_{5}(2 \mathrm{mg} / \mathrm{kg})$ & $1.56 \pm 0.56^{*}$ & $30.45 \pm 0.32^{*}$ & $3.01 \pm 0.56^{*}$ \\
\hline $\mathrm{X}_{6}(2 \mathrm{mg} / \mathrm{kg})$ & $2.87 \pm 0.54^{*}$ & $37.34 \pm 0.34^{*}$ & $3.56 \pm 0.44^{*}$ \\
\hline
\end{tabular}

Values represented mean \pm SEM $(\mathrm{n}=6),{ }^{*} \mathrm{P}<0.05$ vs. control, ${ }^{* *} \mathrm{P}<0.05$ vs. standard.

\section{Discussion}

The two experimental models of anxiety, elevated plus maze and bright and dark arena, are based on the assumption that unfamiliar, non-protective and brightly lit environmental stress provokes inhibition of normal behaviour. This normal behavioural inhibition is further augmented in the presence of fear or anxiety like state. In the elevated plus maze, the open arms are more fear provoking than the closed arms. The ratio of entries, time spent and rearing behaviour in open arms to closed arms reflects the safety of closed arms with relative fearfulness of open arms [18]. The reduction in entry, time spent, total arm entries are the indications of high level of fear or anxiety. Anxiolytic drugs increase the proportion of entries, time spent in open arms. In the bright and dark box paradigm, the brightly lit environment is a noxious environment stressor that inhibits the exploratory behaviour of rodents. Reduction in the number of entries, time spent and rearing behaviour in the bright chamber was regarded as markers of anxiety. Rearing reflects an exploratory tendency of the animal that can be reduced due to a high level of fear [19]. In the present study, the compounds X2 and X3 significantly increased the duration of time spent and number of entries in open arm, time spent in closed arm in EPM test indicating anxiolytic activity in both acute and chronic studies. They also showed an increase in the time spent and the rears in bright arena in the bright and dark arena paradigm. Anxiolytic activity of X2 was found to be greater than diazepam in chronic study.

\section{Conclusion}

The derivatives of benzotriazole $\left(\mathrm{X}_{1}\right.$ to $\left.\mathrm{X}_{6}\right)$ were synthesized with the objective to develop better anxiolytic agents with maximum percentage of yield and optimal anxiolytic activity. The results of the present study suggest that the synthesized compounds $\mathrm{X}_{2}$ and $\mathrm{X}_{3}$ have anxiolytic activity better than Diazepam. It was observed that halogen substituted aromatic compounds were more active than unsubstituted aromatic compounds and aromatic compounds were more active than alkyl substituted compounds. Further investigations with appropriate structural modification of title compound may result in therapeutically useful products. Further studies are required to elucidate the possible mechanism of anxiolytic activity and its usefulness in human beings.

\section{Acknowledgement}

Authors are very thankful to the head, SAIF, Punjab University, Chandigarh and SAIF, CDRI, Lucknow for providing FT-IR and NMR spectra. Head, Institute of Pharmacy, Bundelkhand University, Jhansi (UP), India for providing necessary facilities to carry out this work.

\section{Ethical Approval}

The study was approved by the Institutional Ethics Committee.

\section{References}

1. P Ackerman, S Max (1994) US Patent No: 5, 322, 853, June 21.

2. BV Suma, NN Natesh, CHS Venkataraman, J Jays, V Madhavan (2012) Synthesis and Antibacterial of Some New 1,2,3 Benzotriazoles Derivatives Containing Pyrazolidinedione Moieties. Inter J Pharm Sci 4(1): 169-173.

3. ND Gaikwad, SV Patil, VD Bobade (2012) Synthesis and biological evaluation of some novel thiazole substituted benzotriazole derivatives. Bioorg Med Chem Lett 22 (10): 3449-3454.

4. K Kopańska, A Najda, J Żebrowska, L Chomicz, J Piekarczyk, et al. (2004) Synthesis and activity of $1 \mathrm{H}$-benzimidazole and $1 \mathrm{H}$-benzotriazole 
derivatives as inhibitors of Acanthamoeba castellanii. Bioorg Med Chem 12 (10): 2617-2624.

5. M Purohit, SK Srivastava (1992) Studies in aryloxylated benzotriazoles Indian J Pharm Sci 54(1): 25-27.

6. CM Jamkhandi, PS Kumbhar, JI Disouza, SM Patil (2015) Europ J Pharm med Res 2(4): 1004-1010.

7. G Caliendo, F Fiorino, E Perissutti, B Severino, D Scolaro, et al. (2002) Eur J Pharm Sci 16: 15-28.

8. GK Patil, HC Patil, IM Patil, SL Borse, SP Pawar (2015) Benzotriazole-the molecule of diverse biological activities. World Journal of Pharmacy and Pharmaceutical Sciences 4(5): 532-548.

9. KL Yu, Y Zhang, RL Civiello, KF Kadow, C Cianci, et al. (2003) Fundamental structure-Activity relationships associated with a new structural class of respiratory syncytial virus inhibitor. Bioorg Med Chem Lett 13(13): 2141-2144.

10. KM Dawood, H Abdel Gawad, EA Rageb, M Ellithey, HA Mohamed (2006) Synthesis, anticonvulsant, and anti-inflammatory evaluation of some new benzotriazole and benzofuran-based heterocycles. Bioorganic \& medicinal chemistry 14(11): 3672-3680.

11. AN Bernatowicz, M Łebska, A Orzeszko, K Kopańska, E Krzywińska, et al. (2009) Synthesis of new analogs of benzotriazole, benzimidazole and phthalimide-potential inhibitors of human protein kinase CK2. Bioorg Med Chem 17(4): 1573-1578.
12. Martin EI, Ressler KJ, Binder E, Nemeroff CB (2009) The Neurobiology of Anxiety Disorders: Brain Imaging, Genetics, and Psychoneuroendocrinology. The Psychiatric clinics of North America 32(3): 549-575.

13. Eurniss BS, Hannaford AJ, Smith PWG, Tatchell AR (1989) Vogel's text book of practical organic chemistry, $\left(5^{\text {th }} \mathrm{edn}\right)$, Addison Wesley Longman Ltd, Harlow, England.

14. Fritz Ullmann, Wolfgang Gerhartz, Y Stephen Yamamoto, F Thomas Campbell, Rudolf Pfefferkorn (1985) Ulmann's Encyclopedia of Industrial chemistry A2, 41

15. Soloman G, Fryhle G (2000) Organic chemistry, ( $7^{\text {th }}$ edn) John Willey and Sons Inc. New Delhi, India.

16. Kulkarni SK, Reddy DS (1996) Animal behavioral models for testing antianxiety activity. Meth Find Exp Clin Pharmacol 18: 219-230.

17. Costall B, Domeney AM, Gerrard PA, Kelly ME, Naylor RJ (1988) Zacopride: Anxiolytic profile in rodent and primate models of anxiety. J Pharm Pharmacol 40: 302-305.

18. Pellow G, Chopin P, File SE, Briley M (1985) Validation of open-closed arm entries in elevated plus maze as a measure of anxiety in the rat. Neurosci methods 14: 149-167.

19. Van der poel AM (1979) A note on stretched attention, A behavioral element indicative of an approach-avoidance conflict in rats. Animal Behav 27(2): 446-450.

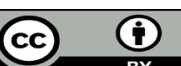

This work is licensed under Creative Commons Attribution 4.0 License

Submission Link:

Submit Article

DOI: 10.32474/DDIPIJ.2018.01.000104

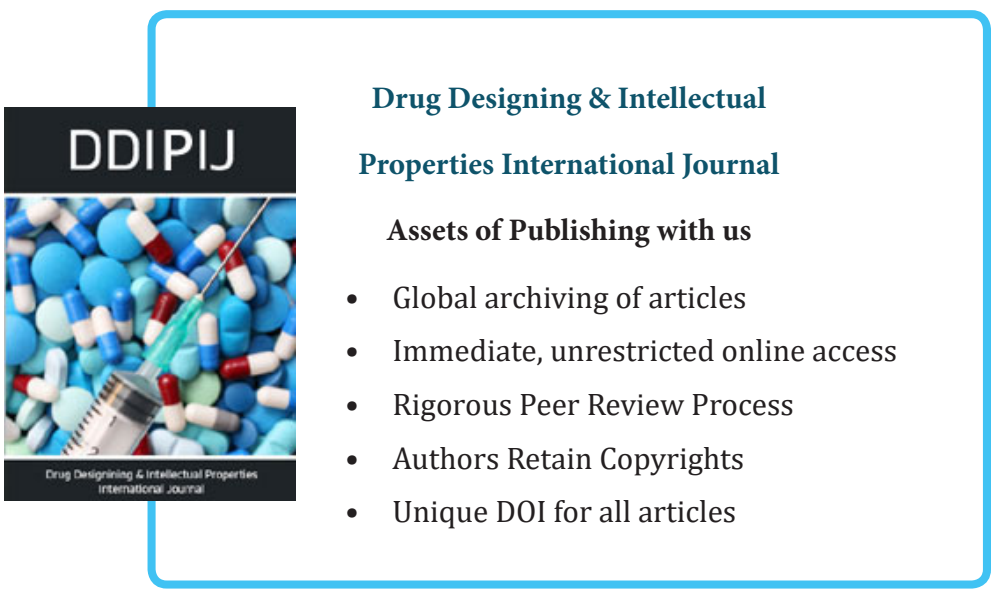

